\title{
CHEMICAL COMPOSITION, IN VITRO ANTIBACTERIAL, AND ANTIOXIDANT ACTIVITY OF ESSENTIAL OIL FROM LEAVES OF AJUGA PARVIFLORA BENTH
}

\author{
SANJAY KUMAR ${ }^{1}$, MOHAMMAD S JAVED ${ }^{1 *}$, PAWAN KUMAR ${ }^{1}$ RISHENDRA KUMAR $^{2}$
}

${ }^{1}$ Department of Chemistry, D.S.B. Campus Kumaun University, Nainital - 263 002, Uttarakhand, India. ${ }^{2}$ Deparatment of Biotechnology, D.S.B. Campus, Kumaun University, Bhimtal Campus, Nainital - 263 136, Uttarakhand, India. Email: msuhail12003@yahoo.co.in

Received: 05 April 2018, Revised and Accepted: 07 July 2018

\section{ABSTRACT}

Objectives: The aim of our study was to evaluate the phytogenic chemical compounds and assess their antibacterial and antioxidant activity of essential oil of Ajuga parviflora Benth. growing in the Himalayan region.

Methods: In the present study, the phytochemical constituents of essential oil were isolated by steam distillation and screened by gas chromatography (GC) and GC-mass spectrometry (GC-MS) analysis from A. parviflora is rich in oxygenated monoterpenoids and sesquiterpenoids. The essential oil was further evaluated for their antibacterial by well-diffusion method and antioxidant activity by 2,2-diphenyl-1-picrylhydrazyl (DPPH) scavenging assay at various concentrations.

Results: The major chemical constituents were $\alpha$-cadinol (21.36\%), $\alpha$-muurolol (14.2\%), cubebol (12.76\%), germacrene D-4-ol (9.6\%), germacrene D (4.32\%), farnesyl acetate (3.58\%), longifolol acetate (2.76\%), and $\beta$-bourbonene (2.35\%) whereas monoterpenoids were minor constituents. The zone of inhibition (ZOI) shown by essential oil against test bacterial strains at concentration of $500 \mu \mathrm{g} / \mathrm{ml}$ to Gram-negative bacteria Pseudomonas aeruginosa (5.6 mm), Escherichia coli (5 mm), Salmonella typhimurium ( $8.6 \mathrm{~mm})$, and Proteus vulgaris $(10.7 \mathrm{~mm})$ and Gram-positive bacteria Bacillus subtilis $(8.3 \mathrm{~mm})$. At the same time, ZOI of standard antibiotic ciprofloxacin against test bacterial strains was P. aeruginosa (9.6 mm), E. coli (14.3mm), S. typhimurium $(19.3 \mathrm{~mm})$, P. vulgaris $(17.8 \mathrm{~mm})$, and B. subtilis $(20.6 \mathrm{~mm})$, respectively. The free radical scavenging property of $A$. parviflora employed by in vitro assay methods like scavenging activity of DPPH was $81 \%$ at $500 \mu \mathrm{g} / \mathrm{ml}$ concentrations, respectively.

Conclusion: Our study showed that $\alpha$-cadinol, $\alpha$-muurolol, and cubebol as the major components in this oil which was absent in previous findings of A. parviflora and essential oil had potent antibacterial and antioxidant activity, respectively.

Keywords: Ajuga, Essential oil, Chemical constituents, Strains, Antibacterial, Antioxidant.

(C) 2018 The Authors. Published by Innovare Academic Sciences Pvt Ltd. This is an open access article under the CC BY license (http://creativecommons. org/licenses/by/4. 0/) DOI: http://dx.doi.org/10.22159/ajpcr.2018.v11s2.28529

\section{INTRODUCTION}

The valley Jammu and Kashmir is regarded as hub for the medicinal plants. The people there were using these medicinal plants for their cure and preventing various diseases since ancient times. There are about a total of 937 plant species belonging to 129 families have been reported from Jammu and Kashmir having traditional medicinal uses [1]. The genus Ajuga belonging to family Lamiaceae represented by 236 genera and up to 7200 species native to Europe, Asia. Ajuga parviflora Benth. is a perennial herbaceous plant also called as bugleweed. Conventionally, the plants have been used in fever, toothache, dysentery, diuretic, anti-inflammatory, and antimicrobial agents. Ajuga plant contains neo-clerodane diterpenes, flavonoids, triterpenes, sterols, and essential oils which possess medicinal properties [2]. The aerial parts of Ajuga bracteosa had characterized by chemical compounds such as hexacosanol, $\beta$-sitosterol, tetracosanoic acid, and $\beta$-sitosterol- $\beta$-D-glucoside [3]. The essential oil of Ajuga chamaepitys (L.) is rich in monoterpenes and sesquiterpenes predominantly $\alpha$-pinene (16.1\%), $\rho$-pinene (34.3\%), and germacrene-D (5.6\%) was the major components [4]. The gas chromatography (GC) and GC-mass spectrometry (GC-MS) analysis of essential oil from aerial parts of Ajuga comata Stapf. were identified as caryophyllene (30.9\%), caryophyllene oxide (24.9\%), (E)- $\beta$-farnesene (12.6\%), eudesmol (3.2\%), and cadinene (3.1\%), and germacrene-D was reported for the first time [5]. Volatile constituents were isolated from hydrodistillation method and were analyzed by GC and GC-MS, namely $\beta$-caryophyllene (22.4\%), $\gamma$-muurolene $(12.7 \%), \gamma$-terpinene $(6.3 \%), \alpha$-humulene (5.8\%), $\alpha$-amorphene (3.8\%), and $\beta$-selinen (2.5\%) were found to be major constituents [6]. The essential oil isolated from the Ajuga austro- iranica Rech.f. was contained pinene (30.5\%), trans-verbenol (7.0\%), caryophyllene oxide $(6.8 \%)$, myrtenol $(6.3 \%)$, 1-octen-3-ol, $(6.2 \%)$, and $\beta$-pinene [7]. The methanolic extract of $A$. parviflora contained alkaloids, namely integerrimine, senecionine, $3 \beta, 17 \beta, 20$-trihydroxy-1oxo-(20R,22R)-witha-5,14,24-trienolide, and 28-hydroxy-14,20-epoxy1-oxo-(22R)-witha-2,5,24-trienolide possessed antifungal activities [8]. The essential oil extracted from the aerial parts of Ajuga chamaecistus Ging. spp. chamaecistus was analyzed which contain $\beta$-pinene $(15.0 \%)$ and linalool (14.5\%) as the major constituents [9]. Methanol, butanol, chloroform, and water extracts of Ajuga turkestanica Rgl. Brig contained phytoecdysteroids and iridoids. The $\mathrm{IC}_{50}$ values for antioxidant activity of water and butanol were $7.24 \pm 0.82$ and $14.57 \pm 1.64 \mu \mathrm{g} / \mathrm{ml}$. The chloroform extract has antimicrobial activities against Staphylococcus aureus and Streptococcus pyogenes. Further investigation of methanol and chloroform contained volatile components, namely Pregna-4,9(11)dien-20-ol-3-on-19-oic acid lactone (19.58\%), 20-methyl-pregna5,17-dien-3 $\beta$-ol (12.93\%), 3,7-dioxocholan-24-oic acid (10.53\%), and betulin $(10.18 \%)$ were detected for the first time [10]. Phytochemical investigation of Ajuga forrestii Diels involves neo-clerodane diterpenes, phytoecdysteroids and stigmastane sterol and iridoid glycosides [11]. Column chromatography, nuclear magnetic resonance spectroscopy, and mass spectroscopy led to isolation and identification of five compounds, namely verbascoside, echinacoside, ajugoside, harpagide, and 8-0-acetylharpagide from Ajuga tenorei C. Presl. known to exert peculiar pharmacological activities [12]. Ethanolic extracts of Ajuga genevensis were rich in caffeic, p-coumaric, and ferulic acids, luteolin, quercetin hyperoside, and apigenin were identified by liquid chromatography-MS analysis. Further, this extract was evaluated to show better results against antimicrobial and antioxidant effects [13]. 
The diterpenoids isolated from Ajuga ciliata Bunge were elucidated as (12S)-1 $\beta, 6 \alpha, 19$-triacetoxy-18-chloro-4 $\alpha, 12$-dihydroxy-neo-clerod13-en-15,16-olide, and 12(S)-6 $\alpha 18,19$-triacetoxy- $4 \alpha, 12$-dihydroxy1b-trigloyloxy-neo-clerod-13-en-15,16-enolide and evaluated for neuroprotective effect against MPP(+)-induced neuronal cell death in dopaminergic neuroblastoma SH-SY5Y cells possessed moderate neuroprotective effects [14]. Our present study reveals the chemical identification and to check their properties of bioactive compounds.

\section{MATERIALS AND METHODS}

\section{Plant material}

The fresh plant material was collected from tarai altitudes of Jodhpur (Doda) and Jammu and Kashmir (India) at an elevated altitude of $1500 \mathrm{~m}$ in the month of August 2016 when plant in good blooming stage. The aerial parts were washed with cold water and their dead skin; dried leaves were skimmed off which were used for the extraction of oil. The preliminary plant identification was done by Prof. P. C. Pandey, Department of Botany, Kumaun University, Nainital. The plant was further confirmed by Botanical Survey of India, Dehradun, Voucher specimen A. parviflora Benth. Acc. No. 118084 where herbarium of plant specimens has been deposited of dried specimens.

\section{Isolation of essential oil}

The essential oil was obtained by steam distillation of fresh plant material (10 kg roots) using copper still fitted with spiral glass condenser. The distillate was saturated with $\mathrm{NaCl}$ and extracted with hexane. The hexane extract is dried with sodium sulfate $\left(\mathrm{Na}_{2} \mathrm{SO}_{4}\right)$ and the solvent removed with Rotovap at moderate pressure and $38^{\circ} \mathrm{C}$ temperature and stored at $4^{\circ} \mathrm{C}$ for further analysis. All chemical and reagents of analytical grade were obtained from Merck, Mumbai, India.

\section{Chemical and reagents}

All chemicals and reagents used were of analytical grade. Hexane, anhydrous $\mathrm{Na}_{2} \mathrm{SO}_{4}$, dimethyl sulfoxide, ether, ethanol, tween 20 , and sodium hypochlorite $(\mathrm{NaOCl})$ were obtained from Merck, Mumbai, India, whereas potato dextrose agar (PDA), potato dextrose broth, 2,2-diphenyl-1-picrylhydrazyl (DPPH), ascorbic acid, $\alpha$-tocopherol, and dextrose (D-glucose) were obtained from Hi-media Pvt. Ltd, Mumbai, India.

\section{Analysis of essential oil \\ GC and GC-MS analysis}

The analysis of the oil was done using a gas chromatograph (Shimadzu GC QP 2010) equipped with RTx-5MS capillary column, $1009701(30.0 \mathrm{~m} \times 0.25 \mathrm{~mm}$, film thickness: $0.25 \mu \mathrm{m})$. The oven temperature $\left(50^{\circ} \mathrm{C}-280^{\circ} \mathrm{C}\right)$ was programmed at $50^{\circ} \mathrm{C}$ for first $2 \mathrm{~min}$, then $3^{\circ} \mathrm{C} / \mathrm{min}$ to $200^{\circ} \mathrm{C}$, and then $10^{\circ} \mathrm{C} / \mathrm{min}$ to $280^{\circ} \mathrm{C}$, after which it was maintained isothermally at $280^{\circ} \mathrm{C}$ for $8 \mathrm{~min} . \mathrm{N}_{2}$ was used as the carrier gas at $113.0 \mathrm{~mL} / \mathrm{min}$. The injector temperature was $250^{\circ} \mathrm{C}$, detector temperature $260^{\circ} \mathrm{C}$, and the injection volume was $0.5 \mu \mathrm{L}$ using a $10 \%$ solution of the oil in n-hexane. The GC-MS analysis was carried out with GC-MS QP 2010 (Shimadzu) fitted with RTx-5MS capillary column, $1009701(30.0 \mathrm{~m} \times 0.25 \mathrm{~mm}$, film thickness: $0.25 \mu \mathrm{m})$. The oven temperature $\left(50^{\circ} \mathrm{C}-280^{\circ} \mathrm{C}\right)$ was programmed at $50^{\circ} \mathrm{C}$ for first $2 \mathrm{~min}$, then $3^{\circ} \mathrm{C} / \mathrm{min}$. to $200^{\circ} \mathrm{C}$, and then $10^{\circ} \mathrm{C} / \mathrm{min}$. to $280^{\circ} \mathrm{C}$. After which, it was maintained isothermally at $280^{\circ} \mathrm{C}$ for $8 \mathrm{~min}$. $\mathrm{N}_{2}$ was used as the carrier gas. The injection volume was $0.5 \mu \mathrm{L}$ and split ratio was 1:90. The mass spectra were taken at $70 \mathrm{eV}$. The percentage of peak area normalization was taken to express the relative percentage of the oil constituents.

\section{Identification of compounds}

Identification of different chemical constituents of the essential oil was done by comparing their Retention Indices/Kovat indices in relation to a series of n-alkanes $\left(\mathrm{C}_{6}-\mathrm{C}_{33}\right)$ indices on the RTx-5MS capillary column, either with those of published data [15] or with authentic samples which were further supported by NIST and WILEY mass spectral library searches. The results are presented in Table 1.
Table 1: Phytochemical composition of aerial parts of essential oil from Ajuga parviflora

\begin{tabular}{|c|c|c|c|}
\hline \multirow[t]{2}{*}{ Compound } & \multirow[t]{2}{*}{$\%$ in the oil } & \multicolumn{2}{|c|}{$\begin{array}{l}\text { Method of } \\
\text { identification }\end{array}$} \\
\hline & & R.I. ${ }^{\mathrm{a}}$ & Others \\
\hline 1-octen-3-ol & 0.52 & 984 & $b, c, d$ \\
\hline 2-nonanone & 0.08 & 1093 & $b, c, d$ \\
\hline Linalool & 1.16 & 1098 & b, c, d \\
\hline Terpineol & 0.14 & 1136 & $b, c, d$ \\
\hline$p$-menth-4-en-3-one & 0.07 & 1146 & $c, d$ \\
\hline$n$-tridecane & 0.09 & 1304 & $c, d$ \\
\hline$\rho$-vinyl-guaiacol & 0.35 & 1314 & $c, d$ \\
\hline eugenol & 0.31 & 1361 & b, c, d \\
\hline$\alpha$-copaene & 1.41 & 1378 & $b, c, d$ \\
\hline$\beta$-bourbonene & 2.35 & 1392 & b, c, d \\
\hline$E$-caryophyllene & 0.18 & 1423 & $b, c, d$ \\
\hline$\beta$-copaene & 0.06 & 1434 & $c, d$ \\
\hline$\gamma$-elemene & 0.61 & 1438 & b, c, d \\
\hline$\alpha$-humulene & 2.08 & 1457 & b, c, d \\
\hline 9-epi-(E)-caryophyllene & 0.50 & 1469 & $c, d$ \\
\hline germacrene D & 4.32 & 1488 & b, c, d \\
\hline$\gamma$-amorphene & 0.18 & 1496 & $c, d$ \\
\hline epi-cubebol & 1.78 & 1499 & b, c, d \\
\hline$\gamma$-cadinene & 2.05 & 1516 & b, c, d \\
\hline cubebol & 12.76 & 1519 & $b, c, d$ \\
\hline$\alpha$-cadinene & 0.32 & 1541 & $c, d$ \\
\hline isospathulenol & 0.30 & 1545 & $c, d$ \\
\hline$\alpha$-calacorene & 0.15 & 1550 & $c, d$ \\
\hline Maaliol & 0.60 & 1570 & $c, d$ \\
\hline Germacrene D-4-ol & 9.60 & 1577 & b, c, d \\
\hline$\beta$-caryophyllene oxide & 0.67 & 1586 & $c, d$ \\
\hline$\beta$-oplopenone & 0.48 & 1608 & $\mathrm{c}, \mathrm{d}$ \\
\hline Humulene oxide & 1.26 & 1612 & b, c, d \\
\hline Epi-cubenol & 0.39 & 1630 & $c, d$ \\
\hline Cubenol & 0.80 & 1646 & b, c, d \\
\hline$\alpha$-muurolol & 14.21 & 1649 & b, c, d \\
\hline$\alpha$-cadinol & 21.36 & 1656 & b, c, d \\
\hline Pentadecanal & 0.39 & 1703 & $c, d$ \\
\hline Oplopanone & 0.10 & 1743 & $c, d$ \\
\hline Khusinol acetate & 0.92 & 1823 & $c, d$ \\
\hline Longifolol acetate & 2.76 & 1827 & b, c, d \\
\hline Farnesyl acetate & 3.58 & 1848 & $b, c, d$ \\
\hline$E, E$-geranyl linalool & 0.58 & 2028 & $c, d$ \\
\hline Abietadiene & 0.14 & 2089 & $c, d$ \\
\hline Trans-totarol & 0.08 & 2317 & $c, d$ \\
\hline Trans-ferruginol & 0.36 & 2334 & $c, d$ \\
\hline Sesquiterpenoids & 12.18 & & \\
\hline Oxygenated sesquiterpenoids & 65.41 & & \\
\hline Monoterpenoids & 0.09 & & \\
\hline Oxygenated monoterpenoids & 2.55 & & \\
\hline Higher hydrocarbon & 7.36 & & \\
\hline Total identified & 87.50 & & \\
\hline Yield & $4.8(4.05 \%$ by & veight) & \\
\hline
\end{tabular}

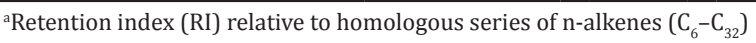
on RTx-5MS capillary column. ${ }^{\mathrm{b}}$ Compound checked by authentic standards compounds. ${ }^{c}$ Retention index (RI). ${ }^{\mathrm{d}} \mathrm{MS}$, NIST08.LIB and WILEY8.LIB libraries spectra and the literature

\section{Pathogenic bacteria and their culture}

The bacterial strains were obtained from MTCC, IMTEC, Chandigarh for this study. The pure culture of bacterial species was maintained in PDA and stored below $4^{\circ} \mathrm{C}$. The pathogenic bacteria Paeudomonas aeruginosa (MTCC 424), Bacillus subtilis (MTCC 441), Escherichia coli (MTCC 443), Proteus vulgaris (MTCC 1771), and Salmonella typhimurium (MTCC 3224) were cultured on Potato dextrose agar medium in sterilized Petri dishes. Pure culture of bacterial strains was prepared by emulsifying single colony in $10 \mathrm{ml}$ of sterilized required broth in tubes and inoculated bacterial cultures were incubated overnight for $24 \mathrm{~h}$.

\section{In vitro antibacterial activity}

For antibacterial activity, well-diffusion method was used to check the antibacterial activity to check the potency of bacterial strains that were 
Table 2: ZOI shown by essential oil from aerial parts of Ajuga parviflora against bacterial strains

\begin{tabular}{|c|c|c|c|c|c|c|c|}
\hline Bacterial strain & M.T.C.C. No. & $100 \mu \mathrm{g} / \mathrm{ml}$ & $200 \mu \mathrm{g} / \mathrm{ml}$ & $300 \mu \mathrm{g} / \mathrm{ml}$ & $400 \mu \mathrm{g} / \mathrm{ml}$ & $500 \mu \mathrm{g} / \mathrm{ml}$ & $600 \mu \mathrm{g} / \mathrm{ml}$ \\
\hline Pseudomonas aeruginosa & 424 & $2.2 \mathrm{~mm}$ & $2.8 \mathrm{~mm}$ & $3.2 \mathrm{~mm}$ & $4.3 \mathrm{~mm}$ & $5.6 \mathrm{~mm}$ & $7.2 \mathrm{~mm}$ \\
\hline Escherichia coli & 443 & $2.8 \mathrm{~mm}$ & $3.5 \mathrm{~mm}$ & $4.1 \mathrm{~mm}$ & $4.6 \mathrm{~mm}$ & $5.1 \mathrm{~mm}$ & $6.9 \mathrm{~mm}$ \\
\hline Bacillus subtilis & 441 & $4.2 \mathrm{~mm}$ & $5.8 \mathrm{~mm}$ & $6.7 \mathrm{~mm}$ & $7.2 \mathrm{~mm}$ & $8.6 \mathrm{~mm}$ & $10.9 \mathrm{~mm}$ \\
\hline Salmonella typhimurium & 3224 & $4.3 \mathrm{~mm}$ & $5.2 \mathrm{~mm}$ & $6.5 \mathrm{~mm}$ & $7.0 \mathrm{~mm}$ & $8.3 \mathrm{~mm}$ & $10.1 \mathrm{~mm}$ \\
\hline Proteus vulgaris & 1771 & $5.2 \mathrm{~mm}$ & $5.7 \mathrm{~mm}$ & $6.8 \mathrm{~mm}$ & $8.0 \mathrm{~mm}$ & $9.1 \mathrm{~mm}$ & $10.7 \mathrm{~mm}$ \\
\hline
\end{tabular}

ZOI: Zone of inhibition

Table 3: Absorbance shown by the Ajuga parviflora and control (ascorbic acid and Vitamin E) at different concentrations

\begin{tabular}{llll}
\hline $\begin{array}{l}\text { Concentration } \\
(\mu \mathrm{g} / \mathrm{ml})\end{array}$ & Absorbance & & \\
\cline { 2 - 4 } & Essential oil & Ascorbic acid & $\boldsymbol{\alpha}$-tocopherol \\
\hline 100 & $0.32 \pm 0.001$ & $0.236 \pm 0.022$ & $0.921 \pm 0.021$ \\
200 & $0.44 \pm 0.003$ & $0.280 \pm 0.032$ & $1.320 \pm 0.004$ \\
300 & $0.56 \pm 0.260$ & $0.520 \pm 0.002$ & $1.890 \pm 0.002$ \\
400 & $0.89 \pm 0.040$ & $0.826 \pm 0.001$ & $2.348 \pm 0.006$ \\
500 & $1.23 \pm 0.160$ & $1.890 \pm 0.043$ & $2.613 \pm 0.013$ \\
600 & $1.67 \pm 0.008$ & $2.520 \pm 0.001$ & $3.124 \pm 0.042$ \\
\hline
\end{tabular}

Values in the column are men of three absorbance results \pm SD. SD: Standard deviation

cultured in nutrient agar medium at $4^{\circ} \mathrm{C}$ for further use. The cultured medium was autoclaved at $121^{\circ} \mathrm{C}$ and $15 \mathrm{lbs}$ for $20 \mathrm{~min}$. Autoclaved medium when cooled and poured in sterilized Petri plates under aseptic conditions until it got solidified. After solidification, the Petri plates were incubated for sterility testing at $28^{\circ} \mathrm{C}$ in incubator. Well was created in dried plates and pipette was used to place $30 \mu \mathrm{l}$ of essential oil into each well. The plates were placed in an incubator at $28^{\circ} \mathrm{C}$ for $24 \mathrm{~h}$. The diameter of zone of inhibition was measured for both bacteria and antibiotic and recorded in $\mathrm{mm}$, held on the back of inverted plates [16].

\section{In vitro antioxidant activity}

The DPPH assay was done according to the method described by Brand William et al. 1995 [17]. The DPPH $0.0039 \mathrm{~g}$ was dissolved in ethanol and made up to $100 \mathrm{ml}$ with double-distilled water. The ethanol (20\%) $20 \mathrm{ml}$ and $80 \mathrm{ml}$ double-distilled water were prepared. The $100 \mu \mathrm{M}$ DPPH (50 $\mu \mathrm{l})$ was added to equal volume of $20 \%$ ethanol to generate $400 \mu \mathrm{l} \mathrm{DPPH}$. The oil samples of different concentrations were taken in different test tubes and added DPPH $400 \mu \mathrm{l}$ and make volume up to $100 \mu \mathrm{l}$ with doubledistilled water. Then, it was shaken vigorously and taken in the dark for $20 \mathrm{~min}$ at room temperature. The reduction in absorbance was recorded at $520 \mathrm{~nm}$ in UV-VIS spectrometer. Ascorbic acid and $\alpha$-tocopherol were used as standard and controlled absorbance of DPPH was taken without adding oil sample, and all the assays were carried out in triplicate. Scavenging effect (\%) of free radical DPPH was calculated as:

$$
\text { Scavenging effect } \%=\frac{\begin{array}{l}
\text { Absorbance of control }- \\
\text { Absorbance of oil sample }
\end{array}}{\text { Absorbance of control }} \times 100
$$

$\mathrm{IC}_{50}$ assay was calculated graphically using curve by plotting antioxidant capacity or percentage inhibition versus corresponding sample concentrations.

\section{Statistical analysis}

For all the tests, the mean values and standard deviations were calculated and data were analyzed using SPSS 16.0 statistical software. The one-way analysis of variance was applied for calculating the results. The means were compared by Duncan tests at level of significance of $p \leq 0.05$.

\section{RESULT AND DISCUSSION}

The oil was dominated by oxygenated sesquiterpenoids (65.41\%) and sesquiterpenoids $(12.18 \%)$ whereas monoterpenoids $(0.09 \%)$

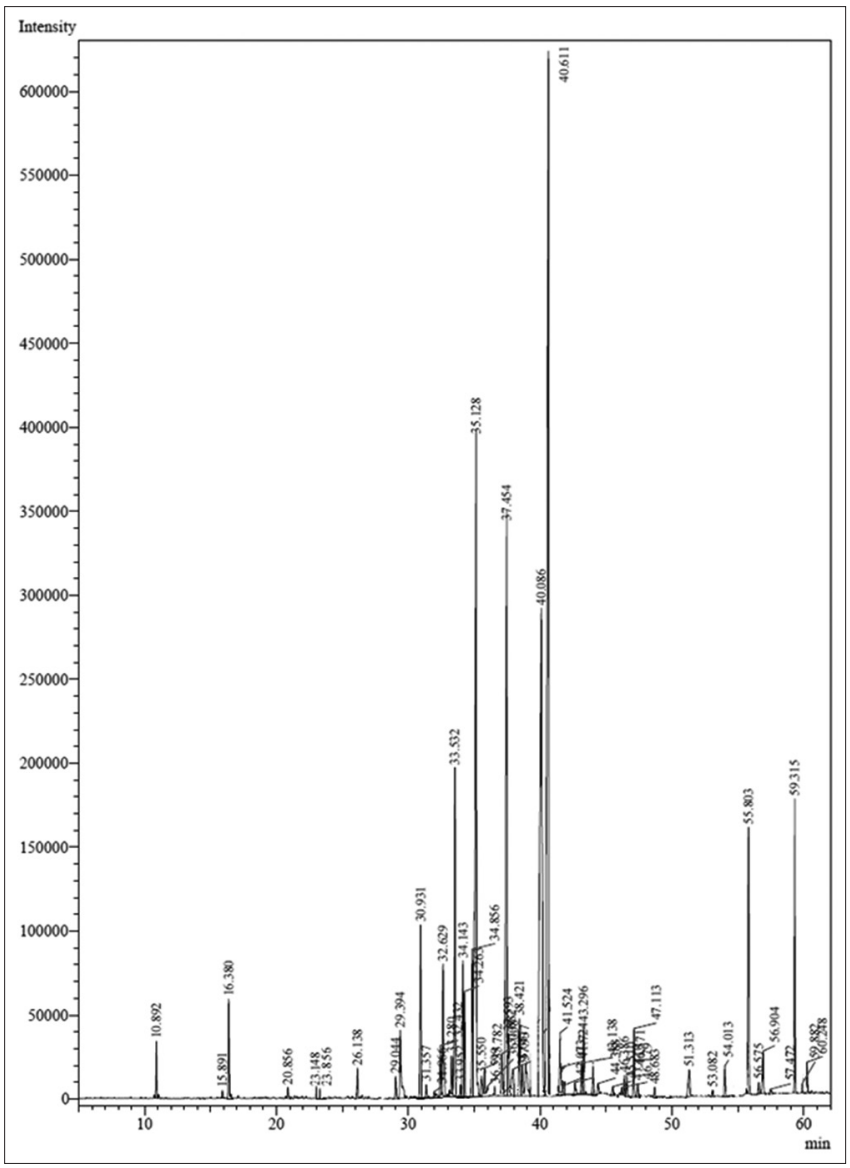

Fig. 1: Gas chromatogram of Ajuga parviflora

and oxygenated sesquiterpenoids $(2.55 \%)$ constituted as minor components. The essential oil with major constituents is $\alpha$-cadinol (21.36\%), $\alpha$-muurolol (14.2\%), cubebol (12.76\%), germacrened-4-ol (9.6\%), germacrene D (4.32\%), fernesyl acetate (3.58\%), longifolol acetate $(2.76 \%)$, and $\beta$-bourbonene (2.73\%) (Fig. 1 and Table 1). The essential oil of herb A. parviflora contains $\alpha$-cadinol and a-muurolol terpenoids as major constituents which were absent in previous analysis A. parviflora [6]. This change in composition is due to environmental adaptation climatic conditions and altitude factor of the plants.

The pathogenic bacterial strains incubated for 1 day for $P$. aeruginosa (MTCC 424), B. subtilis (MTCC 441), E. coli (MTCC 443), P. vulgaris (MTCC 1771), and S. typhimurium (3224) at $28 \pm 2^{\circ}$. The potency of oil was tested against Gram-positive and Gram-negative bacteria. The study shows that the oil has varied effect ranges from $2.2 \mathrm{~mm}$ to $10.9 \mathrm{~mm}$ in both Gram-positive and Gram-negative bacteria. The oil shows highest effect against $B$. subtilis $(10.9 \mathrm{~mm})$ and $P$. vulgaris $(10.7 \mathrm{~mm})$ whereas the standard antibiotic ciprofloxacin against test bacterial strains was $P$. aeruginosa $(9.6 \mathrm{~mm})$, E. coli $(14.3 \mathrm{~mm})$, S. typhimurium $(19.3 \mathrm{~mm}), P$. vulgaris $(17.8 \mathrm{~mm})$, and $B$. subtilis (20.6 $\mathrm{mm})$, respectively The minimum inhibitory concentration of oil from A. parviflora in comparison to standard antibiotic 
Table 4: Percentage scavenging activity of different concentration of essential oil and controls

\begin{tabular}{llll}
\hline $\begin{array}{l}\text { Concentration } \\
(\boldsymbol{\mu g} / \mathbf{m l})\end{array}$ & $\begin{array}{l}\text { \%age of DPPH scavenged by essential } \\
\text { oil }\end{array}$ & $\begin{array}{l}\text { \%age of DPPH scavenged by ascorbic } \\
\text { acid }\end{array}$ & $\begin{array}{l}\text { \%age of DPPH scavenged by } \\
\boldsymbol{\alpha} \text {-tocopherol }\end{array}$ \\
\hline 100 & 21.4 & 23.4 & 35.2 \\
200 & 40.3 & 41.2 & 56.4 \\
300 & 52.4 & 55.6 & 60.2 \\
400 & 70.1 & 68.3 & 71.8 \\
500 & 81.0 & 71.2 & 84.0 \\
600 & 89.1 & 89.3 & 94.3 \\
\hline
\end{tabular}

DPPH: 2,2-diphenyl-1-picrylhydrazyl

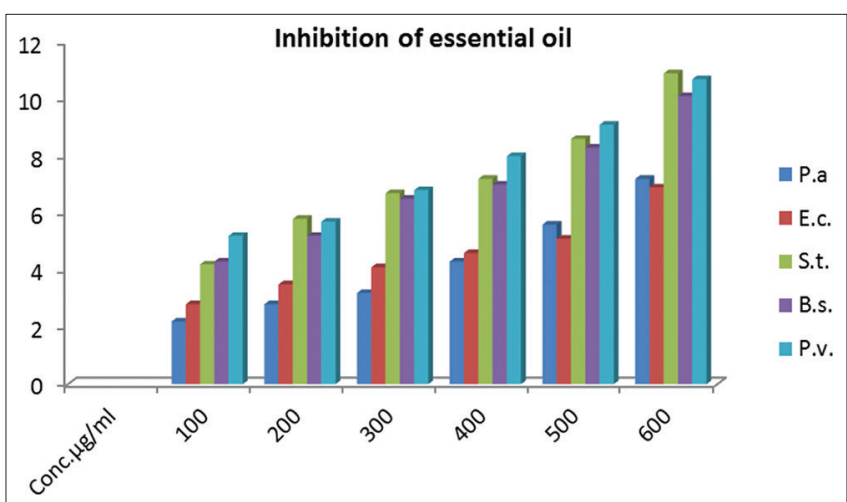

Fig. 2: Effect of essential oil on test bacterial strain at different concentrations (P.a.: Pseudomonas aeruginosa, E.c.: Escherichia coli, B.s.: Bacillus subtilis, S.t.: Salmonella typhimurium, P.v.: Proteus vulgaris)

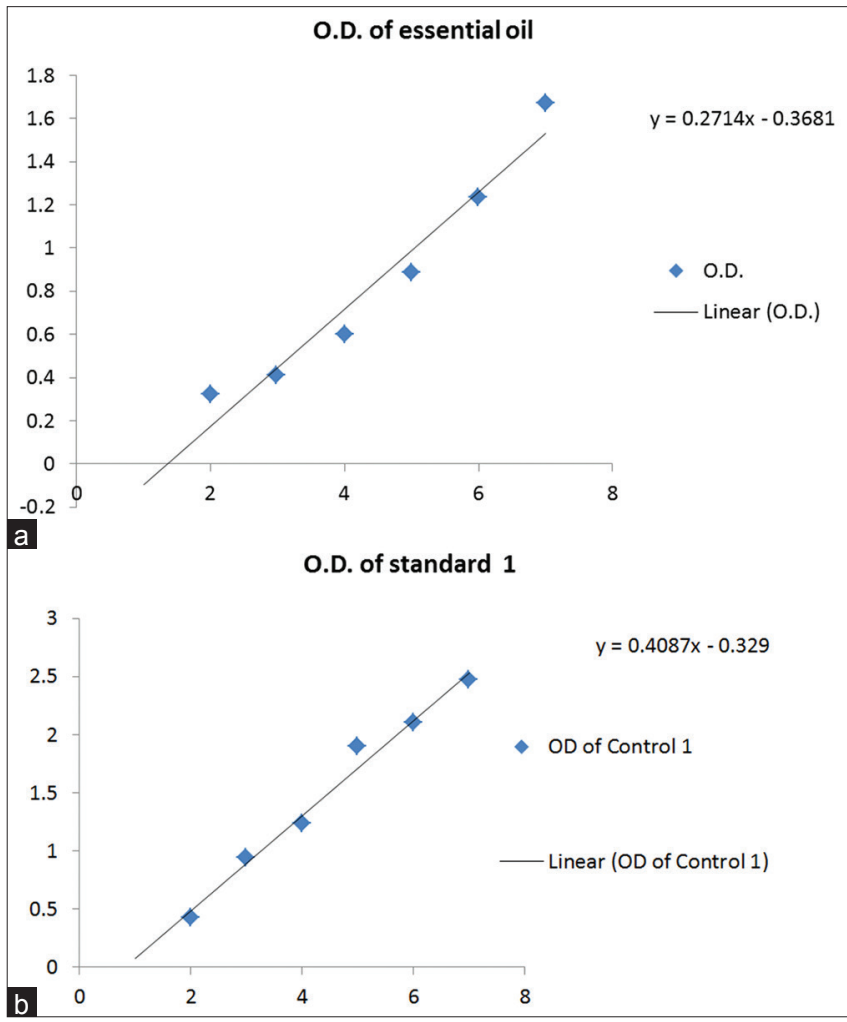

Fig. 3: ( $a$ and b) O.D. graph of essential oil and control 1

(ciprofloxacin) showed moderate effect (Table 2 and Fig. 2). The results are indicating that $A$. parviflora have potential use in medicinal and phytotherapy.

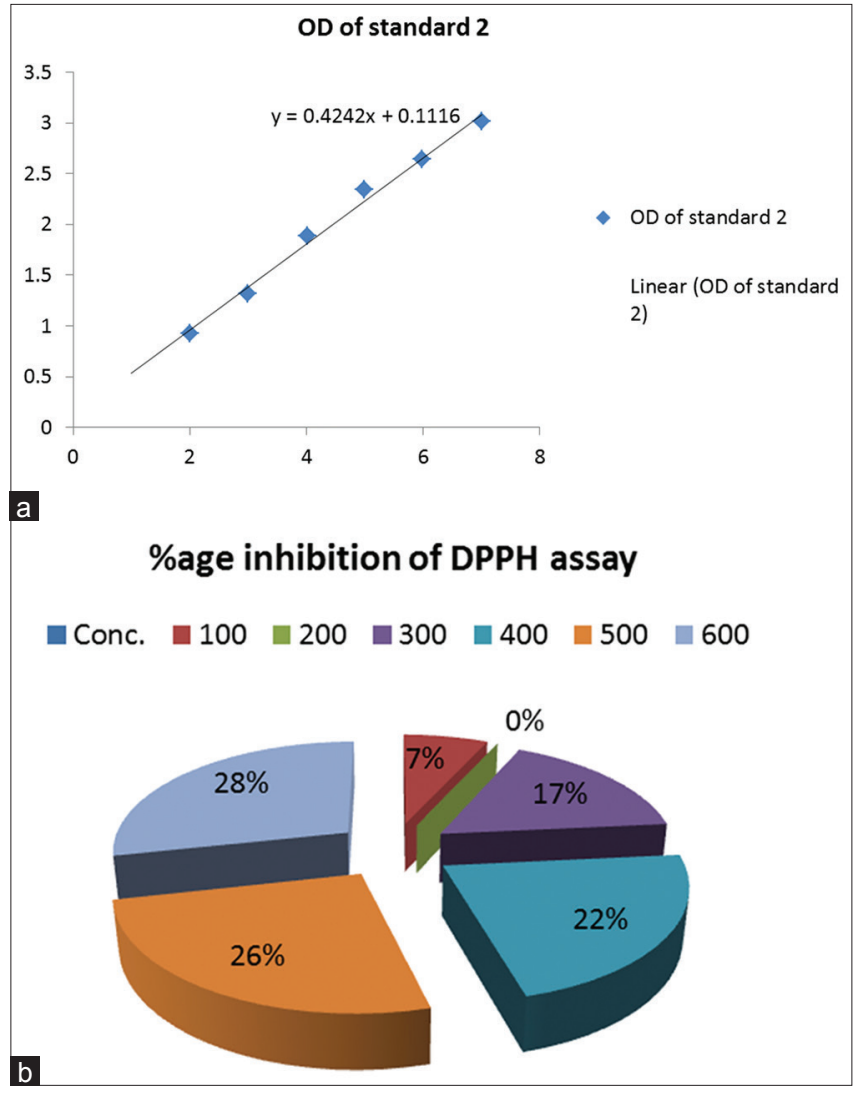

Fig. 4: (a and b) O.D. graph of control 2 and pie chart showing \%age inhibition of 2,2-diphenyl-1-picrylhydrazyl assay at various concentrations

This study affirms that in vitro antioxidant activity of essential oil from aerial parts of $A$. parviflora was comparable to those of standard ascorbic acid and Vitamin E [18]. Higher absorbance indicated higher reducing power. The present study indicated that the oil at concentration of $100-$ $600 \mu \mathrm{g} / \mathrm{ml}$ range from $21.4 \%$ to $89.1 \%$ could play an important role in the management of oxidative stress (Tables 3 and 4). Thus, it was considered that the essential oil had antioxidant activity against DPPH radical (Figs. 3 and 4).

\section{CONCLUSIONS}

This study showed that $\alpha$-cadinol, $\alpha$-muurolol, and cubebol as the major components in this oil which was absent in previous findings of $A$. parviflora. The essential oil from this plant has been responsible for its antidiuretic, anticancer, anti-inflammatory, antioxidant, and antibacterial activities [19]. However, the synergic effect is found to be responsible for its bioactivity. As a result of its activity, it can be used as bactericides and antioxidant which is more safe and eco-friendly as compared with synthetic chemicals. Thus, we hope that the phytochemical investigation helps in coping different diseases of our region. 


\section{ACKNOWLEDGMENTS}

The authors are highly thankful to Prof. P. C. Pandey, Kumaun University, Nainital and Kumar Ambrish, Botanical Survey of India, Dehradun, India, for plant identification. We are also thankful to Prof. A. B. Melkani, H.O.D Chemistry and Prof. S. P. S. Mehta, D. S. B. Campus, KU, Nainital, for providing the necessary facilities for smooth research. Furthermore, we are thankful to Dr. Rishendra Kumar, Department of Biotechnology, Bhimtal Campus, Nainital (India), for their valuable necessarily guidance.

\section{REFERENCES}

1. Gairola S, Sharma J, Bedi YS. A cross-cultural analysis of Jammu, Kashmir and Ladakh (India) medicinal plants use. J Ethan Pharmacol 2014;155:925-86.

2. Israili Z, Badia L. Ethanopharmacology of the plants of genus Ajuga. Pak J Pharm Sci 2009;22:425-62.

3. Bhakuni RS, Shukla YN, Thakur RS. Chemical constituents of Ajuga bracteosa. Indian J Pharm Sci 1987;49:225-6.

4. Azizan J, Fallah-Bagher-Shaidaei H, Kefayati H. Chemical Constituents of Ajuga chamaepitys growing in Iran. J Essent Oil Res 2002;14:344-5.

5. Karami A. Essential oil composition of Ajuga comata Stapf. from Southern Zagros, Iran. Nat Prod Res 2016;31:359-61.

6. Singh P, Prakesh O, Pant AK. Essential oil composition of Ajuga parviflora Benth. growing in Western Himalayan region of Uttarakhand. J Essent Oil Bearing Plants 2015;18:697-701.

7. Javidnia K, Miri R, Soltani M, Khosravi AR. Chemical constituents of essential oil of Ajuga ausrto-iranica Rech.f. (Lamiaceae) from Iran. J Essent Oil Res 2010;22:392-4.

8. Nawaz HR, Malik A, Khan PM, Riaz M. Chemical constituents of Ajuga parviflora. Verlag Z Naturforsch Tubingen 2000;55b:100-3.

9. Mazloomifar A, Ssber-Tehrani M, Rustaiyan A, Masoudi S. Chemical composition of the oil of Ajuga chamaecistus spp. chamaecistus from
Iran. J Essent Oil Res 2003;15:17-8.

10. Mamadalieva NZ, El-Readi MZ, Ovidi E, Wink M. Anti-proliferative, antimicrobial and antioxidant activities of the chemical constituents of Ajuga turkestania. Phytopharmacol 2013;4:1-18

11. Chen T, Diao QY, Yu HZ, Ruan J. Phytochemical, cytotoxic and chemotaxonomic study on Ajuga forrestii Diels (Labiatae). Nat Prod Res 2017;31:1-5

12. Frezza C, Venditti A, Cecco MD, Bianco A. Iridoids and phenylethanoid glycosides from aerial parts of Ajuga tenorei, an endemic Italian species. Nat Prod Res 2016;31:1-6.

13. Toiu A, Vlase L, Arsene AL, Oniga I. LC/UV/MS profile of polyphenols, antioxidant and antimicrobial effects of Ajuga genevensis L. extracts. Farmacia 2016;64:5357.

14. Guo P, Li Y, Xu J, Jin DQ, Gao J, Huo W, et al. Neo-clerodane diterpenes from Ajuga ciliata Bunge and their neuroprotective activities. Fitoterapia 2011;82:1123-7.

15. Adam RP. Identification of Essential Oils Components by Gas Chromatography/Mass Spectrometry. Carol Stream, IL: Allured Publishing Corporation; 2007.

16. Leelasuphakul W, Himmanae P, Chuentchitt S. Growth inhibitory properties of Bacillus subtilis strains and their metabolites against the green model pathogen (Penicellium digitatum sacc.) of citrus fruit. Postharvest Biol Technol 2008;48:113-21.

17. Brand-Williams W, Cuvelier ME, Berset C. Use of free radical method to evaluate antioxidant activity. Lebensem Wiss U Technol 1995;28:2530 .

18. Toiu A, Vlase L, Gheldiu AM, Vonder D, Oniga I. Evaluation of the antioxidant activity and antibacterial potential of bioactive compounds from Ajuga reptans extracts. Pharmacia 2017;65:351-5.

19. Ganaie HA, Ali MN, Ganai BA, Kaur J, Ahamad M. GC-MS analysis and mutagenic and antimutagenic activity of ethyl acetate extract of Ajuga bracteosa Wall ex. Benth: An endemic medicinal plant of Kashmir Himalayan. J Clin Toxicol 2016;6:1000288-96. 